\title{
Analisis Stres Finansial Pada Gender
}

\author{
Peter Garlans Sina \\ Alumni Magister Manajemen UKSW-Salatiga \\ Lidya Theresye Raturomon \\ Pengajar Fakultas Keguruan Ilmu Pendidikan UKAW-Kupang
}

\begin{abstract}
Abstrak
The aim of this research is to determine the tendency of financial stress as well as the differences between gender categories. The sampling method used is the census with a chi square technique. After the analysis, the results show that both of the hypothesis are accepted, which means that there is a tendency to experience a financial stress and the women tend to experience higher financial stress compared with men. This is due to an mistake in the management of personal finance.

Key word : personal finance, financial stress, Gender
\end{abstract}

Key word : personal finance, financial stress, Gender

\section{A. Pendahuluan}

Perilaku buruk dalam mengelola keuangan dapat mengakibatkan berbagai efek negatif dan salah satunya adalah stres keuangan (Garman, Leech \& Grable, 1996). Pengetahuan dan implementasi atas praktik keuangan pribadi yang sehat, idealnya perlu dipunyai dan dilakukan oleh setiap orang. Apabila terjadi seseorang mengalami stres keuangan (financial stres) maka akan menggangu kinerja pribadi seperti terperangkap dalam utang (Karasulu, 2008). Davis dan Mantler (2004) mempertegas dengan menyatakan bahwa beberapa efek negatif diantaranya adalah mengalami depresi, anxienty, menurunnya kesehatan mental dan fisik, menurunnya harga diri, pesimis, mengkonsumsi alkohol, ketidakpuasan hidup dan lain-lain.

Merujuk pada ulasan di atas, Kim dan Garman (2003) serta Marks (2005) menjelaskan bahwa stres keuangan merupakan salah satu hal yang perlu direduksi oleh siapa saja. Ditemukan juga bahwa perempuan bertendensi lebih tinggi mengalami stres keuangan dibandingkan laki-laki. Sementara itu Mills, Grasmick, Morgan dan Wenk (1992) menemukan hasil bertentangan bahwa lakilaki lebih mudah mengalami stres keuangan dibanding perempuan sehingga menghambat kemampuan mengolah keuangan. Adanya temuan yang berbeda ini menarik peneliti untuk mengkaji ulang.

Berpijak pada beberapa bukti sebelumnya, tampak bahwa terdapat tidak konsisten antara berbagai hasil temuan terkait apakah laki-laki atau perempuan yang lebih tinggi mengalami stres keuangan dan hal inilah yang menarik peneliti untuk mengkaji ulang. Untuk itu dalam penelitian ini akan meneliti stres keuangan antara dua kategori gender untuk mendapatkan hasil yang robust. Dengan 
demikian, tujuan yang ingin dicapai dalam riset ini adalah untuk mengetahui apakah ada tendensi mengalami stres finansial serta untuk mengetahui apakah ada perbedaan antara kategori gender dalam mengalami stres keuangan.

Secara umum manajemen keuangan didefinisikan sebagai seni dan ilmu mengelola uang. Lanjut, manajemen keuangan merupakan proses perencanaan, analisa dan pengendalian kegiatan keuangan (Gitman dalam Krihna, Rofaida dan Sari (2010)). Sementara itu, Shefrin (2007) mempertegas melalui pernyataan bahwa pengeluaran dan penghasilan rumah tangga seolah-olah senantiasa kejar mengejar untuk saling memenangkan perlombaan, dan dapat diduga seringkali yang menjadi pemenangnya adalah pengeluaran sehingga benar adanya jika ada pepatah yang mengatakan bahwa perilaku rumah tangga terhadap uang lebih penting dibandingkan seberapa banyak uang yang dimiliki. Namun, banyak rumah tangga yang belum menyadari pentingnya pengelolaan keuangan, dengan alasan jumlah penghasilan kecil sehingga terlalu kecil untuk dikelola, sementara yang berpenghasilan besar juga merasa punya banyak uang sehingga tak memerlukan pengelolaan keuangan lagi. Pada prinsipnya terdapat dua jenis perilaku individu terhadap uang, yakni penabung (saver) atau pembelanja (spender).

\section{Stres Keuangan}

So-Hyun Jo menjelaskan bahwa stres keuangan lebih di sebabkan oleh personal, keluarga dan situasi keuangan lainnya. Stres keuangan diduga disebabkan oleh keadaan yang sulit dari kehidupan seseorang karena banyaknya akitivitas-aktivitas fundamental sehari-hari terkait tingkatan sumber daya keuangan pribadi. Stress keuangan pada umumnya terjadi karena ketidakcukupan keuangan untuk memenuhi berbagai kebutuhan diri atau pun seluruh anggota keluarga. Ketidakcukupan keuangan tersebut disebabkan masalah keuangan yang dihadapi keluarga/individu karena salah mengelola keuangan. Konkritnya adalah kebiasaan berbelanja yang tidak normal sehingga mereduksi uang untuk ditabung. Dan, hal ini terus terjadi tanpa ada usaha untuk memperbaikinya atau tanpa berusaha melunasi utang untuk konsumsi dengan melakukan penghematan. Hal tersebut disebabkan kesalahan dalam mengelola penerimaan sehingga lebih besar pasak daripada tiang atau mengalami defisit. Namun apabila keluarga atau individu mampu mengelola keuangannya dengan tepat atau bijak maka mengalami stres keuangan dapat direduksi atau bahkan dapat dihindari. Roos (2007) menambahkan bahwa mengalami stres keuangan membuat orang kurang atau bahkan tidak mengalami kepuasan dalam bekerja. Efek lanjutannya adalah pekerja akan kurang termotivasi sehingga kinerja menjadi menurun. Selain itu juga, mengalami stres keuangan akan mempengaruhi pola interaksi dalam keluarga sehingga keseimbangan atau keharmonisan akan terganggu.

\section{Gender}

Marzuki menyatakan bahwa gender sering diidentikkan dengan jenis kelamin (sex), padahal gender berbeda dengan jenis kelamin. Gender sering juga dipahami sebagai pemberian dari Tuhan atau kodrat Ilahi, padahal gender tidak 
semata-mata demikian. Secara etimologis kata 'gender' berasal dari bahasa Inggris yang berarti 'jenis kelamin' (Echols \& Shadily, 1983). Dari beberapa definisi di atas dapat dipahami bahwa gender adalah suatu sifat yang dijadikan dasar untuk mengidentifikasi perbedaan antara laki-laki dan perempuan dilihat dari segi kondisi sosial dan budaya, nilai dan perilaku, mentalitas, dan emosi, serta faktor-faktor nonbiologis lainnya. Gender berbeda dengan sex, meskipun secara etimologis artinya sama sama dengan sex, yaitu jenis kelamin. Sementara itu, dalam Women's Studies Encyclopedia menjelaskan bahwa gender adalah suatu konsep kultural yang berupaya membuat pembedaan (distinction) dalam hal peran, prilaku, mentalitas, dan karakteristik emosional antara laki-laki dan perempuan yang berkembang dalam masyarakat.

\section{Stres Keuangan}

Bailey, Woodiel, Turner dan Young (1998) menjelaskan bahwa stres keuangan akan mengakibatkan berbagai persoalan dan salah satunya adalah menurunnya produktifitas kerja, kehilangan keseimbangan untuk mencapai tujuan dan hilangnya kepuasan ketika melakukan sesuatu. Kim, Sorhaindo, dan Garman (2006) memperkuat dengan penjelasan bahwa stress keuangan dapat disebabkan oleh peningkatan utang. Peningkatan utang akan mempengaruhi kemampuan rumah tangga atau individu untuk menabung atau pun berinvestasi untuk jangka panjang. Akibat lanjutan dari mengalami stress keuangan adalah ketidakpuasan dalam hubungan (relation) keluarga serta dalam bekerja, dan akhirnya berakhir pada pada kemalasan untuk bekerja (absenteeism). Merujuk pada berbagai akibat karena mengalami stres keuangan, keempat peneliti menjelaskan bahwa salah satu upaya untuk menguranginya adalah dengan memperbaiki manajemen keuangan pribadi.

Choi (2008) mempertegas lagi dengan menyatakan bahwa stres keuangan terjadi karena rumah tangga atau individu mengalami utang yang berlebihan sehingga tidak mampu mendanai keperluan lainnya. Dengan kata lain yaitu stres keuangan terjadi karena rumah tangga atau individu salah mengelola (mismanagement) keuangan pribadinya. Lanjut bahwa hal ini akan memicu persoalan dalam rumah tangga sehingga menimbulkan berbagai persoalan yang menimbulkan stres. Penjelasan lainnya adalah Nicol (2009) bahwa stres keuangan merupakan deskripsi dari kesulitan yang dialami individu atau rumah tangga untuk memenuhi kebutuhan hidup karena kekurangan uang. Dengan kata lain, stres keuangan merupakan kondisi kekurangan atau ketidakcukupan uang yang dialami rumah tangga atau individu untuk memenuhi berbagai kebutuhan hdup karena salah mengelola uang yang diperoleh (income).

$\mathrm{H} 1$ : terdapat tendensi mengalami stres keuangan

\section{Stres Keuangan Dan Gender}

Creed, Muller dan Machin (2001), Armour (2005) serta Marican, Zakaria dan Rahman (2012) menyatakan bahwa stres keuangan berdampak pada kesejahteraan keluarga. Hal ini karena stres keuangan menyumbang sebesar dua puluh lima persen atas kesejahteraan. Spesifiknya yaitu keluarga atau individu akan merasa kehilangan berbagai sumber ekonomi seperti keuangan serta materi 
lainnya sehingga memicu stres keuangan yang berakhir pada semkain terperosoknya keluarga atau individu dalam kesulitan keuangan. Atkinson (2001) menegaskan lagi dengan pernyataan bahwa mengalami stres keuangan mengakibatkan keluarga atau pun individu tidak mampu menyiapkan persediaan uang untuk membiayai kebutuhan-kebutuhan yang tidak terduga.

Terkait gender, penelitian Mark (2005) menemukan bahwa perempuan bertendensi mengalami stres keuangan dibandingkan laki-laki. Hal ini karena perempuan memiliki pendapatan yang lebih rendah daripada laki-laki dan itu disebabkan laki-laki lebih mungkin melakukan penilaian diri dibandingkan perempuan. Bermodalkan penilaian diri yang lebih baik akan lebih mungkin mengetahui sumber masalah yang dihadapi dan segera mencari solusi atas permasalahan yang dihadapi. Kim dan Garman (2003) juga menemukan hasil serupa bahwa perempuan lebih mungkin mengalami stres keuangan. Namun penyebabnya berbeda, yakni perempuan relatif memiliki pendidikan keuangan yang kurang baik dibandingkan laki-laki sehingga lebih mudah mengalami stres keuangan.

Financial Finnese Reports (2011) menemukan bahwa laki-laki lebih baik dari perempuan untuk mereduksi mengalami stres finansial. Penyebabnya adalah perempuan memiliki kemampuan mengelola keuangan yang rendah dibanding laki-laki. Serupa Financial Finnese Reports (2012) serta Davis dan Mantler (2004) juga menemukan bahwa laki-laki lebih baik daripada perempuan untuk mereduksi mengalami stres finansial, namun penyebabnya adalah perempuan lebih rendah dalam memiliki keyakinan untuk mencapai tujuan keuangan serta kurang percaya diri bahwa kondisi keuangan saat ini mampu di kendalikannya.

Weatherburn (2011) serta Fox dan Bartholomae (2011) juga menemukan bahwa perempuan rentan mengalami stres finansial. Beberapa penyebabnya diantaranya adalah kehilangan teman atau kelaurga, sakit, ketidakmampuan mendapatkan pekerjaan, hidup tanpa rencana dan lain-lain. Namun apabila diperas maka dapat disimpulkan bahwa penyebabnya adalah ketidakmampuan mengelola uang sehingga mengalami kekeliruan dan berakhir pada mengalami stres finansial.

Segi lain, Delafrooz dan Paim (2011), Orton (2007), Fin Mark Trust 2004 serta Collins (2010) menjelaskan terkait literasi keuangan dengan stres keuangan bahwa memiliki literasi keuangan yang kurang tinggi akan berdampak pada manejemen keuangan yang kurang baik sehingga memicu kesejahteraan yang rendah. Efek lanjutannya adalah orang yang memiliki literasi keuangan rendah lebih mungkin mengalami stres finansial.

Alcon (1999) serta Lusardi dan Mitchell (2008, 2009) menguatkan dengan temuannya bahwa perempuan terbukti memiliki literasi keuangan yang rendah dibandingkan laki-laki. Terkait dengan penelitian ini, ada indikasi mengapa perempuan lebih mungkin mengalami stres keuangan dibandingkan laki-laki karena perempuan bertendensi memiliki literasi keuangan yang lebih rendah. Dengan literasi keuangan yang lebih rendah, perempuan bertendensi mengalami 
kesalahan dalam mengelola uang dan mungkin saja akan terperangkap dalam utang yang berlebihan sehingga lebih berpeluang mengalami stres keuangan dibandingkan laki-laki. Dengan demikian, merujuk pada penjelasan-penjelasan sebelumnya, rumusan hipotesis yang dibangun dalam penelitan ini adalah sebagai berikut :

$\mathrm{H}$ 2: perempuan bertendensi lebih tinggi mengalami stres keuangan daripada lakilaki

\section{B. Metode Penelitian}

Penelitian ini merupakan penelitian eksplanasi yang bertujuan untuk memberi jawaban atas pertanyaan mengapa dengan menjelaskan alasan terjadinya suatu fenomena (Supramono \& Utami, 2004). Untuk menjawab pertanyaan mengapa, peneliti akan melakukan uji beda.

Jenis data yang digunakan dalam penelitian ini yaitu data primer yang diperoleh melalui survey, dengan cara menyebarkan kuesioner secara langsung kepada guru-guru SMU Kristen Mercusuar Kupang-NTT. Sedangkan data sekunder ditujukan pada tata usaha (TU) untuk mengetahui jumlah populasi guru SMU Kristen Mercusuar Kupang-NTT.

Metode pengumpulan data yang digunakan adalah metode survey dengan teknik kuesioner. Skala yang digunakan adalah skala Likert. Cara menyebarkan kuesioner secara langsung kepada guru-guru SMU Kristen Mercusuar KupangNTT.

Variabel dalam penelitian ini adalah : Stres Keuangan merupakan variabel Independen, yaitu variabel yang mempengaruhi atau menjadi penyebab besar kecilnya variabel lain. Masing-masing dimensi diukur dengan skala Likert dengan skala 5 poin: (1) Sangat Tidak Sesuai, (2) Tidak Sesuai, (3) Cujup Sesuai, (4) Sesuai, (5) Sangat Sesuai.

\section{Tabel 1 \\ Definisi Operasionalisasi Variabel}

\begin{tabular}{|c|c|c|}
\hline Variabel & Definisi & Indikator \\
\hline Stres Keuangan & $\begin{array}{l}\text { Deskripsi dari kesulitan yang } \\
\text { dialami individu atau rumah } \\
\text { tangga untuk memenuhi } \\
\text { kebutuhan hidup karena } \\
\text { kekurangan uang (Nicol, } \\
\text { 2009). }\end{array}$ & $\begin{array}{l}\text { 1. Apakah kamu memiliki anggaran } \\
\text { belanja yang melebihi penerimaanmu dalam } \\
\text { satu bulan. } \\
\text { 2. Keluargaku kurang memiliki cukup } \\
\text { uang untuk membeli pakaian baru yang } \\
\text { diinginkan. } \\
\text { 3. Keluargaku kurang memiliki uang } \\
\text { yang memadai untuk membeli peralatan rumah } \\
\text { yang seharusnya dimiliki. } \\
\text { 4. Apakah kamu tidak memiliki } \\
\text { kecukupan uang untuk membiayai dana } \\
\text { pendidikan atau pun aktivitas-aktivitas sosial. }\end{array}$ \\
\hline
\end{tabular}




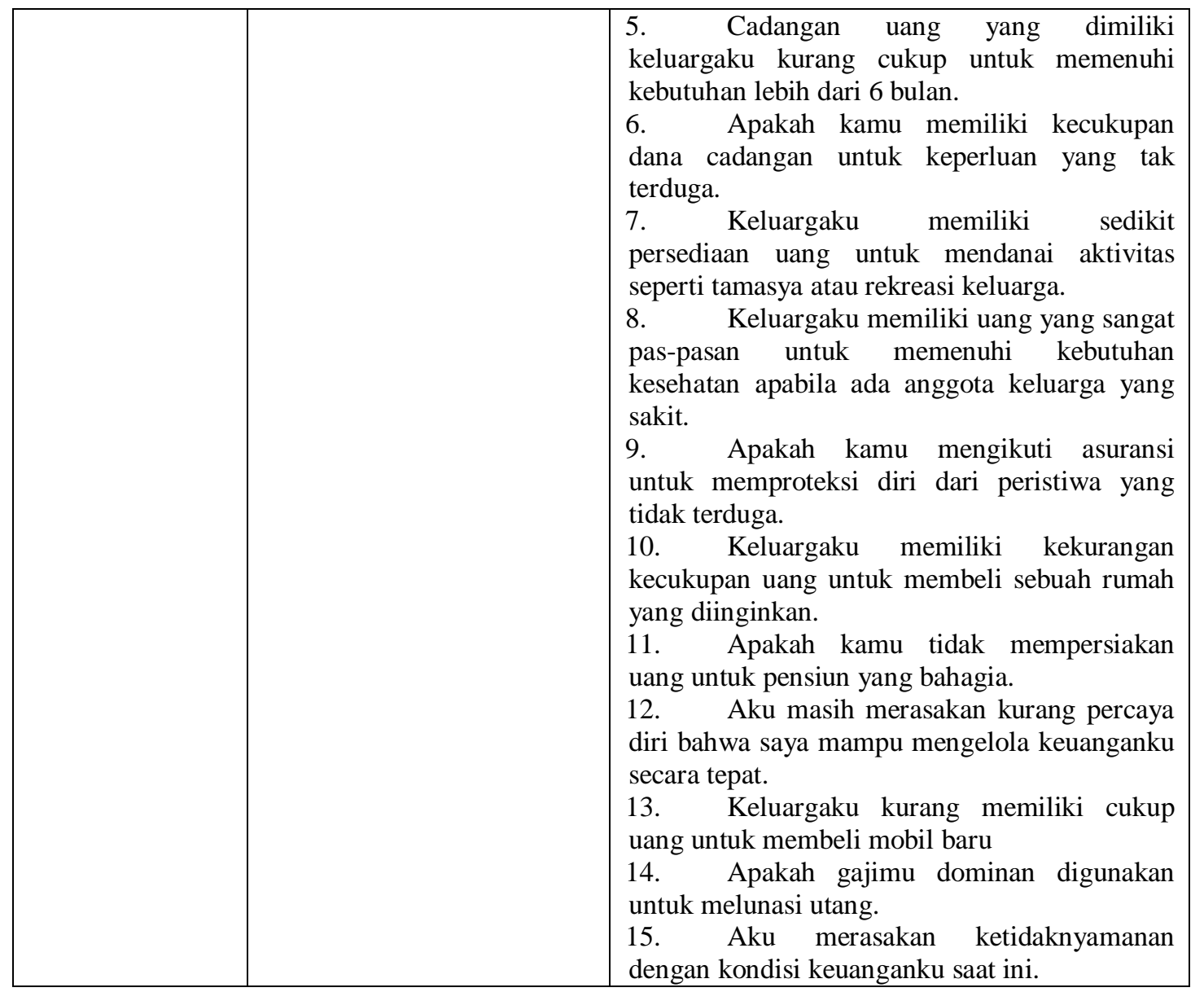

Sumber: Loc Thai (2011)

Populasi dalam penelitian ini sekaligus menjadi sampel yang berjumlah 35 responden. Dengan demikian, teknik pemilihan sampel yang digunakan dalam penelitian ini adalah metode sensus.

Setelah variabel didefinisikan secara operasi dan menerapkan teknik penskalaannya, selanjutnya harus diyakinkan bahwa instrumen yang dibuat harus mengukur senyatanya (actually) dan seakuratnya (accurately) apa yang harus diukur dari konsep. Pengukuran konsep senyatanya (actually) berhubungan dengan validitas dan pengukuran seakuratnya (accurately) berhubungan dengan reliabilitas atau seberapa akurat dapat diandalkan. 
Pengujian validitas dalam penelitian ini menggunakan pengujian validitas konstruk. Validitas konstruk menunjukkan seberapa baik hasil-hasil yang diperoleh dari penggunaan suatu pengukur sesuai dengan teori yang digunakan untuk mendefinisikan suatu konstruk. Pengujian validitas dilakukan dengan melakukan korelasi bivariate antara masing-masing skor indikator dengan total skor konstruk. J ika korelasi menunjukkan hasil yang signifikan ( $p$ value $<0.01$ ), maka dapat dikatakan bahwa masing-masing indikator pertanyaan tersebut adalah valid (Ghozali, 2001).

Uji reliabilitas merupakan tingkat kebebasan dari random errors sehingga alat ukur yang digunakan dapat memberi hasil yang konsisten. Reliabilitas merupakan faktor kondisional bagi validitas tetapi data yang reliabel belum tentu valid. Jadi, reliabilitas menyangkut akurasi konsistensi, dan stabilitas alat ukur. Suatu kuesioner dikatakan handal jika jawaban seseorang terhadap pernyataan adalah konsisten atau stabil dari waktu ke waktu (Ghozali 2001). Reliabilitas dalam penelitian ini diukur dengan menggunakan Cronbach's Alpha. Jika nilai Cronbach's Alpha > 0.6, maka instrumen penelitian dapat dikatakan reliabel. Range reliability:

\section{Hasil dan Pembahasan}

Proses pengambilan data berlangsung dari tanggal Tanggal 30 agustus hingga 3 september 2012 pada guru-guru SMU Kristen Mercusuar Kupang-NTT. Angket sendiri disebar sebanyak 35 buah dengan metode sensus. Dari 35 kuesioner yang disebar, sebanyak 32 yang berhasil dikumpulkan untuk dianlisis lebih lanjut. Hal ini berarti terdapat 3 buah kuesioner yang tidak dikembalikan dan sebanyak 32 kuesioner yang akan dianlisis lebih lanjut.

Penelitian ini melibatkan 32 responden yang merupakan guru-guru SMU Kristen Mercusuar Kupang-NTT. Dari sampel tersebut, diperoleh responden yang berjenis kelamin perempuan sejumlah $68 \%$ dan yang berjenis kelamin laki-laki sejumlah $32 \%$. Sedangkan responde berdasarkan usia diperoleh hasil yaitu $71 \%$ antara usia 23 hingga 33 tahun dan 29\% antara usia 34 hingga 44 tahun. Terkait pengukuran validitas diperoleh hasil bahwa 4 item pertanyaan dari 15 item pertanyaan memiliki nilai dibawah 0,30. Tepatnya adalah item pertanyaan 8,12, 14 dan 15 (lihat lampiran). Sedangkan hasil pengukuran reliabilitas setelah mengeliminasi pertanyaan, diperoleh nilai alpha cronbach sebesar 0, 820. Dengan demikian analisis dilanjutkan pada tahapan selanjutnya.

Pada bagian ini dibahas deskripsi jawaban responden dengan cara melihat distribusi jawaban responden secara keseluruhan dari konsep stres finansial.

Tabel 2 Interval Kategori Stres Keuangan dan Tidak Stres Keuangan

\begin{tabular}{|c|c|c|c|}
\hline Interval & Kategori Jawaban & $\mathbf{N}$ & $\mathbf{\%}$ \\
\hline $1-3.4$ & Stres Keuangan & 28 & $87 \%$ \\
\hline $3.41-5$ & Tidak Stres Keuangan & 4 & $13 \%$ \\
\hline
\end{tabular}


Merujuk pada tabel di atas, tampak bahwa guru-guru SMU Kristen Mercusuar Kupang-NTT dominan mengalami stres finansial yakni sebesar 87\%. Sedangkan hanya $13 \%$ saja yang tidak mengalami stres finansia.

Tahapan ini akan dijabarkan hasil uji hipotesis, selengkapnya adalah seperti pada tabel dibawah ini.

Tabel 3 Hasil Uji Hipotesis

\begin{tabular}{|l|c|l|r|}
\hline \multicolumn{2}{|c|}{ Hipotesis Pertama } & \multicolumn{2}{c|}{ Hipotesis Pertama } \\
\hline & FS & & Gender \\
\hline Chi-square & 18 & Chi-square & 4,5 \\
\hline Df & 1 & Df & 1 \\
\hline Asymp. Sig. & 0 & Asymp. Sig. & 0,034 \\
\hline
\end{tabular}

Tabel 4.2 di atas menunjukkan nilai sig sebesar 0,000 yang menunjukkan diterimanya $\mathrm{H} 1$. Hal ini berarti bahwa ada tendensi mengalami stres finansial pada guru-guru SMU Kristen Mercusuar Kupang-NTT. Hal yang sama juga pada hipotesis kedua yakni menunjukkan nilai sig sebesar 0,034 yang menunjukkan diterimanya H2. Hal ini berarti bahwa guru perempuan SMU Kristen Mercusuar Kupang-NTT bertensensi mengalami stres finansial yang lebih tinggi dibandingkan guru laki-laki SMU Kristen Mercusuar Kupang-NTT.

Hasil pengujian membuktikan bahwa ada tendensi mengalami stres finansial pada responden. Lanjut, dapat dijelaskan bahwa mayoritas guru-guru SMU Kristen Mercusuar Kupang-NTT mengalami stres finansial sehingga temuan dalam penelitian mendukung temuannya Kim dkk (2006) dan Choi (2008). Terbuktinya mengalami stres finansial mengindikasikan bahwa responden dalam penelitian ini bertendensi mengalami kekeliruan dalam mengelola keuangan pribadi sehingga kesimbangan arus kas masuk dan keluar mengalami ketidaseimbangan, dimana arus kas keluar bertendensi lebih banyak dibandingkan arus kas masuk.

Temuan lainnya adalah ada indikasi bahwa mayoritas guru-guru SMU Kristen Mercusuar Kupang-NTT kurang memiliki persiapan dana pensiun. Tanpa memiliki kesiapan untuk pensiun, diketahui bahwa peluang mengalami ketidakcukupan uang ketika sudah tidak bekerja lagi meningkat sehingga bertendensi akan 
bekerja lebih keras lagi untuk mencukupi kebutuhan hidup. Dengan demikian, tanpa persiapan dana pensiun yang memadai mendukung temuan sebelumnya bahwa pola pengelolaan keuangan pribadi (personal finance) saat ini lebih mendahulukan pengeluaran-pengeluaran daripada menabung secara reguler. Dengan kata lain, pola keuangan yang dilakukan cenderung pada akumulasi aset konsumsi dibandingkan aset produktif.

Selain itu, temuan menarik lainnya adalah responden dalam penelitian ini relatif tidak memiliki kecukupan uang untuk mendanai kebutuhan-kebutuhan keuangan yang tidak diprediksi atau tidak diduga. Lanjut, hal ini menandakan bahwa respon dalam penelitian ini belum memiliki pemahaman yang mendalam tentang peluang akan peristiwa yang diharapkan dan yang tidak diharapkan sama besarnya. Spesifiknya yaitu mayoritas guru-guru SMU Kristen Mercusuar KupangNTT relatif belum memiliki kecukupan dana untuk mendanai kebutuhan apabila terjadi peristiwa yang tidak diduga. Tanpa memiliki kecukupan dana untuk kebutuhan uang tidak diduga akan bertendensi menggunakan utang sebagai sumber pendanaan. Dan hal ini membuat posisi keuangan sangat rentan mengalami utang yang berlebihan apabila tidak diantisipasi saat ini.

Terkait pengujian hipotesis kedua, terbukti bahwa responden perempuan bertendensi lebih tinggi mengalami stres finansial dibandingkan laki-laki. Lanjut, temuan pada hipotesis kedua ini mendukung temuannya Kim dan Garman (2003), Weatherburn (2011) serta Fox dan Bartholomae (2011) bahwa laki-laki lebih mungkin mampu mereduksi stres keuangan dibandingkan perempuan. Oleh karena itu, perempuan lebih mungkin membuat keputusan keuangan yang keliru sehingga memicu stres finansial. Efek lanjutannya adalah perempuan bertendensi memiliki tabungan yang lebih rendah atau bahkan kurang disiplin dalam menabung dibandingkan laki-laki.

Kondisi sebelumnya juga didukung oleh data mentah (see appendix) bahwa responden perempuan lebih condong mengalami stres finansial dibandingkan lakilaki. Hal ini mengindikasikan bahwa perempuan lebih rentan mengalami stres finansial dibandingkan laki-laki. Lebih mungkinnya mengalami stres finansial oleh perempuan menandakan bahwa pemahaman keuangan guru-guru perempuan SMU Kristen Mercusuar Kupang-NTT kurang tinggi dibandingkan laki-laki. Dengan demikian, dapat dijelaskan bahwa responden perempuan memerlukan bantuan atau nasihat keuangan dibandingkan responden laki-laki.

\section{Simpulan dan Saran}

Merujuk pada analisis data diperoleh kesimpulan bahwa terdapat tendensi mengalami stres finansial serta ada perbedaan antara kedua kategori gender, dimana perempuan lebih mungkin mengalami stres finansial dibandingkan laki-laki. Diterimanya kedua hipotesis dalam penelitian ini menandakan bahwa guru-guru SMU Kristen Mercusuar Kupang-NTT mengalami kekeliruan dalam mengelola keuangan. Selain itu. Saran bagi penelitian mendatang yakni mencari faktor-faktor penyebab dari 
stres finansial serta menspesifikkan stres keuangan seperti membandingkan responden yang berkerja pada bidang keuangan dan yang bukan.

\section{Daftar Pustaka}

Alcon, A. 1999. Financial Planning and the Mature Woman. FPA Journal - Financial Planning and the Mature Woman

Armour, S. 2005. Money worries hinder jon performance. USA Today retrieved september 2006

Atkinson, W. 2001. Drowning in debt. HR Magazine, 46,(8)

Bailey, W. C, Woodiel, D. K, Turner, M. J. \& Young, J. 1998. The Relationship of Financial Stress to Overall Stress and Satisfaction. Personal Finances and Worker Productivity 1998, Vol. 2, No. 2

Choi, L. 2009. Financial Stress and Its Physical Effects On Individuals and Communities. Community Development INVESTMENT REVIEW

Collins, J. M. 2010. A Review of Financial Advice M odels and the Take-Up of Financial Advice. Center for Financial Security WP 10-5

Creed, P. A, Muller, J. \& M achin, M. A. 2001. The role of satisfaction with occupational status, neuroticism, financial strain and categories of experince in predicting mental health in the unemployed. Personality and individual differences, 30, 435-447

Davis, C. G. \& Mantler, J. M. 2004. The Consequences of Financial Stress for Individuals, Families, and Society. Centre for Research on Stress, Coping, and Well-being Department of Psychology Carleton University

Delafrooz, N. \& Paim, L. Hj. 2011. Determinants of financial wellness among Malaysia Workers. African Journal of Business Management Vol. 5(24), pp. 10092-10100, 14 October, 2011 Available online at http://www.academicjournals.org/A|BM DOI: 10.5897/AJBM 10.1267 ISSN 1993-8233 @ 2011 Academic Journals

Echols \& Shadily,1983. An Indonesian-English Dictionary.Cornell University Press

Financial Finnese Reports 2012. 2011 Research Financial Stress. 2011 Financial Finesse, Inc.

FinMark Trust. 2004. Financial Literacy Scoping Study \& Strategy Project. ECIAfrica Consulting Final Report March 2004

Fox, J. J. \& Bartholomae, S. 2011. Economic Stress and Families. www.google.com - financial stress

Garman, E. T. Leech, I. E. \& Grable, J. E. 1996. The Negative Impact Of Employee Poor Personal Financial Behaviors On Employers. Financial Counseling and Planning, Volume 7, 1996

Ghozali, I. 2001. Aplikasi Analisis Multivariat Dengan Program SPSS, Badan Penerbitan UNDIP, Semarang

Karasulu, M . 2008. Stress Testing Household Debt in Korea. IM F WP/08/255

Kim, J. \& Garman, R. T. 2003. Financial Stress and Absenteeism: An Empirically Derived Research Model. Financial Counseling and Planning, Volume 14(1), 2003 
Kim, J, Sorhaindo, B. \& Garman, E. T. 2006. Relationship between Financial Stress and Workplace Absenteeism of Credit Counseling Clients. Original Paper J Fam Econ Iss DOI 10.1007/s10834-006-9024-9

Krishna, A, Rofaida, R. \& Sari, M. 2010. Analisis tingkat literasi keuangan di kalangan mahasiswa dan faktor-faktor yang mempengaruhinya (Survey pada Mahasiswa Universitas Pendidikan Indonesia). Proceedings of The 4th International Conference on Teacher Education; Join Conference UPI \& UPSI Bandung, Indonesia, 8-10 November 2010

Loc Thai. 2011. Financial Sterss Questionnaire. http://georgiavacc.blogspot.com/2011/12/newyear-financial-stress-questionnaire.html

Lusardi, A \& Mitchell, O. S. 2009. Financial literacy: evidence and implication for financial education. Trends and issues may 2009

Marican, S, Zakaria, S. H. \& Rahman, A. A. 2012. Financially Stressed Employees At WorkPlace: A M alaysian Perpective. International Journal of Research in Social Sciences Volume 2, IsSue 2 ISSN: 2249-2496

Marks, G. N. 2005. Income Poverty, Subjective Poverty and Financial Stress. Melbourne Institute of Applied Economic and Social Research

Marzuki. Kajian Awal Tentang Teori-Teori Gender. www.goole.com - Pdf gender. Diunduh 3 Februari 2012

Mills, R. J. Grasmick, H. G, Morgan, C. S. \& Wenk, D. 1992. The effects of gender, family satisfaction, and economic strain on psychological well-being. Family Relations, 42, 440-445.

Nicol, A. 2009. The experience of financial stress in Australia: the role of life events and prior Stress. Dept of Families, Housing, Community Services and Indigenous Affairs

Orton, L. 2007. Financial Literacy: Lessons from International Experience. CPRN Research Report September 2007

Roos, M. B. 2007. The Impact Of Financial Stress on Employee Job Satisfaction. Executive Development, Bedford Texas

Shefrin , H. 2007. Behavioral corporate finance: decision that create value. McGrawHill/Irwin

So-Hyun Jo. Review Of Related Literature Chapther II. www.goole.com - Pdf personal finance. Diunduh 3 Februari 2012

Supramono \& Utami, I. 2004. Desain Proposal Penelitian, Andi Offset, Yogyakarta

Weatherburn, D. 2011. Personal stress, financial stress and violence against women. Crime And Justice Bulletin 